\title{
The role of palaeoecology in conserving African ecosystems
}

\author{
Lindsey Gillson \\ Plant Conservation Unit, Department of Biological Sciences, University of \\ Cape Town, South Africa
}

\begin{abstract}
Africa holds critical and unique biodiversity, but conservation is challenging because of the complexity of landscapes and their history, and the multitude of drivers and stakeholder perspectives. Palaeoecology can help in developing a nuanced understanding of landscape history that can inform pressing conservation issues, including climate change integrated conservation strategies, fire management, management of herbivores and rewilding, ecosystem restoration, sustainable use of natural resources, and management of cultural landscapes. To be useful, however, the data from palaeoecological proxies needs to be converted into metrics that are useful and accessible to conservationists and managers, requiring rigorous calibration against modern and instrumental data sets, alongside sound chronologies. Palaeoecologists can help in enhancing the applied value of their work by interpreting it in ways that are underpinned by sound ecological theory in ways that are relevant to pressing conservation questions. The design of projects and the interpretation and application of data can be used as starting points for interdisciplinary, collaborative approaches with stakeholders. Finally, the modelling of palaeoecological data can help stakeholders to explore landscape changes and the effect of management interventions under different scenarios of climate and land-use change in the future.
\end{abstract}

\subsection{INTRODUCTION}

Africa's landscapes are home to important biodiversity hotspots as well as the world's only intact megafaunal assemblage (Archer et al. 2018). They are also characterised by a large rural population, whose livelihoods directly depend on ecosystem services, alongside rapidly changing socio-economic contexts that include urbanisation and development. Conservation in Africa takes place both inside and outside of protected areas and both approaches present challenges and opportunities. Developing conservation strategies that benefit both biodiversity and people depends on developing and understanding of landscape history both in terms of ecological variability and cultural context.

In the early days of conservation, the idea of maintaining, preserving or restoring 'balance' was prevalent, and ideas of equilibrium were also reflected in early ecological theory. Maintaining populations at fixed carrying capacity was an approach common in southern Africa, while in East Africa strict preservation of 'wilderness' - areas perceived, often wrongly, to have been little modified by people - was a dominant conservation ideal (Gillson 2015). Added to this, many colonial governments perceived fire to be destructive and implemented policies of fire suppression, disrupting traditional burning practices, such as seasonal mosaic burning (Gillson et al. 2019). However, more recent approaches to conservation accept that variability, flux and disturbance are normal to most populations and landscapes, and this raises a need for a long-term 
perspective that allows managers to explore resilience and variability over centennial-millennial timescales.

Many African National Parks were founded in the early decades of the twentieth century, when ecosystems were likely to have been in an atypical state. Though most African landscapes have been managed by people for millennia, the combined impacts of fire suppression, removal or disruption of traditional management, and the decimation of megafaunal populations from the $19^{\text {th }}$ century are likely to have led to atypically higher tree density in savannas. This high tree density is likely to be further exacerbated by the effects of $\mathrm{CO}_{2}$ fertilisation, which benefits $\mathrm{C}_{3}$ plants such as savanna trees and shrubs, more than $\mathrm{C}_{4}$ plants, including savanna grasses, and is likely to play a role in bush encroachment (Bond and Midgley 2012; Midgley and Bond 2015; Wigley et al. 2009). On the other hand, some savannas were cleared of trees because of charcoal production or to make way for agropastoralism, and woody vegetation subsequently recovered following land abandonment (Blair et al. 2018; O'Connor et al. 2014). Therefore, interplay between environmental change and the role of anthropogenic influence, both positive and negative, are important aspects of landscape history that needs to be considered in conservation planning and ecosystem management.

Amid all of this complexity, science is only part of the basis for conservation decisions, while stakeholder values, cultural context and local perspectives must also be considered (Rogers et al. 2013). A central challenge that palaeoecologists can contribute to is developing nuanced, interdisciplinary and inclusive understanding of landscape history (Marchant and Lane 2014; Marchant et al. 2018; Mustaphi et al. 2019), that can then be applied in defining and refining conservation and management goals (Gillson 2015; Githumbi et al. 2020; Wolfe et al. 2007). Here I discuss the role of palaeoecology in understanding and managing the drivers of landscape changes, then identify some ways forward in applying this knowledge to conservation practice.

\subsection{UNDERSTANDING, PREDICTING AND MANAGING THE DRIVERS OF LANDSCAPE CHANGE}

\subsubsection{Climate}

Past warm periods such as the African Humid Period and the Mediaeval Warm Period can provide valuable insights into the response of ecosystems to climate change, as well as the feedbacks between fire, climate and vegetation structure (Lüning et al. 2017). They have a particularly important role in informing and refining the development of models that simulate changes in vegetation cover based on climatic and other variables. This has been demonstrated in work modelling the greening of the Sahara during the mid-Holocene. Palaeoecological data indicated that models based on orbital forcing alone were under-estimating the magnitude and extent of the greening event (Lézine et al. 2011; Pausata et al. 2020; Tierney et al. 2017). This helped in shaping more complex models that include for example feedbacks between vegetation and climate (Chen et al. 2020; Pausata et al. 2020; Rachmayani et al. 2015).

Most predictions of future climate change agree that Africa's climate will get warmer, but there is a high degree of uncertainty regarding future changes in rainfall. While it is commonly expected that warmer climates bring higher rainfall due to increased ocean evaporation, this is not always the case, and some areas are expected to experience aridification and/or increased extreme events (Engelbrecht et al. 2013; Pinto et al. 2018). This is of critical importance to areas where agriculture is rain fed and already marginal (Pohl et al. 2017). Reconstructing past climates and particularly the interaction between temperature and rainfall can help in understanding the interactions between regional climate systems and assist in more accurate downscaling of global models (Lüning et al. 2018). Furthermore, palaeoecological data can help in understanding vegetation-climate-fire feedbacks that in turn shape the distribution of fire-adapted ecosystems 
(Bond and Midgley 2012). It can also inform the manipulation of drivers such as fire that interact with climate. Information such as this is critical in designing conservation strategies that consider climate change, for example, potential shifts in the distribution of ecosystems and species as well as identifying populations that are likely to be most vulnerable or most resilience to climate change (Hannah et al. 2002). In a world of finite space and limited conservation resources, a sound basis for conservation prioritisation in a changing climate is critical (Foden et al. 2019).

\subsubsection{Fire}

Fire is a critical component of many African ecosystems, and is essential in maintaining grasslands, savannas and heathlands in areas of sub-Saharan Africa that have rainfall that is high enough to support forest (Bond et al. 2005). Nevertheless, fire management remains a contested issue in many areas, due to risk to property and life, as well as due to lack of understanding of its important ecological role (Bowman et al. 2013; Gillson et al. 2019). Many colonial governments believed fire to be detrimental and implemented policies of fire suppression in ecosystems that were naturally fire adapted (Moura et al. 2019). Later, when attempts to suppress fire proved futile, these policies were replaced by prescribed burns at regular intervals (van Wilgen et al. 2014). Policies of fire suppression and prescribed burning disrupted traditional fire management and homogenised the fuel load, leading to artificially intense and widespread fires in subsequent decades (Humphrey et al. 2020).

People have managed fire for millennia, for example by patch mosaic burning, which involves burning small patches of vegetation starting in the early dry season (Laris 2011). As different patches are burned at different times, this creates patches of vegetation with different post-fire ages (time since burned). Species assemblages often change throughout post-fire succession, and therefore a heterogeneous mosaic of different post-fire ages provides a wider range of habitat, biodiversity and ecosystem services than would be present had only a single, large fire occurred (Parr and Brockett 1999). In addition, such skilful management of fire helps to prevent late season wildfires that homogenise the landscapes (Humphrey et al. 2020), and can be used to manipulate the balance of forest and savanna elements at the savanna-forest ecotone (Fairhead and Leach 1996).

Palaeoecology is essential in understanding the impacts of anthropogenic fire management and the effects of fire suppression and management. Such records can in addition contribute to debates of anthropogenic 'savannisation' and the extent of human influence on forest ecosystems (Veldman 2016; Willis et al. 2004). Studying fire history through the charcoal record can help in determining whether current fire policies are within the historical range of variability. They may also assist in reinstating the skillful management of fire by communities who have incorporated fire management into their livelihoods for millennia (Humphrey et al. 2020).

\subsubsection{Herbivory}

Herbivores have both direct and indirect effects on vegetation structure and composition through physical impact on plant biomass and their influence on ecosystem processes, such as nutrient cycling and seed dispersal (Cromsigt et al. 2018). Changes in herbivore density thus have major implications for ecological function and biodiversity conservation (Hempson et al. 2015). Hunting, disease and manipulation of carnivore populations have all altered wild and domestic herbivore numbers, leading to declines in population size and distribution of many wild species in the late $19^{\text {th }}$ and early $20^{\text {th }}$ centuries (Venter et al. 2017). In southern Africa, reports of vast herds of wildebeest and springbok were reported in the early $20^{\text {th }}$ century, while such herds have vanished from today's landscapes (Home 1874; Skead et al. 2007; Venter et al. 2017). In the $20^{\text {th }}$ century, there have also been wide fluctuations in populations of both wild and domestic herbivores in response to, for example, changes in domestic and local markets for meat and wool, 
intensification of agriculture, a transition to game farming, as well as illegal hunting of rhino and elephant (Beinart 2003). These changes would have directly affected vegetation structure and composition and influenced nutrient cycling, physical disturbance and fire regimes through changes in biomass accumulation.

The use of coprophilous fungal spores is commonly used to pinpoint the timing and effects of megafaunal extinctions (Burney et al. 2003; Feranec et al. 2011), but there are also possibilities for addressing ecological questions about changes in herbivore abundance and how they affected vegetation on more recent timescales of decades to centuries (Ekblom and Gillson 2010; Goethals and Verschuren 2019). This information is invaluable in informing the management and restoration of functional herbivore-driven landscapes (Fuhlendorf et al. 2009). It could also play a role, alongside pollen data, in addressing questions about the impacts of elephants on their habitat, specifically whether elephant impact on trees is unprecedented due to their confinement in small areas, or whether the loss of tree cover is actually a return to the less wooded landscapes of the $17^{\text {th }}$ and $18^{\text {th }}$ century (Gillson 2015; Veldman 2016).

With urbanisation continuing apace in Africa, and the effects of government grants on rural livelihoods, game farming and re-wilding are likely to become increasingly attractive options for conservation (Hoogendoorn et al. 2019) (though the effects of the current COVID-19 pandemic on these options remain to be seen (Lindsey et al. 2020)). Palaeoecologists can help managers decide what should the landscapes look like, and how many herbivores there should be (Hempson et al. 2015; Venter et al. 2017).

\subsubsection{Anthropogenic Influence}

Many African National Parks were founded in the early decades of the twentieth century, a time when many landscapes had been affected by intensive human impact including changes in fire and fauna as well as changing climate and rising $\mathrm{CO}_{2}$, and as well as changes in land use including sedentarisation (i.e. loss of transhumant lifestyles) and land abandonment. There is therefore a role for palaeoecology, specifically fossil pollen and phytolith analysis, in exploring variability in ecosystem structure and composition, particularly in terms of woody vegetation density. These data allow ecosystem managers to distinguish, for example, whether increasing tree cover is a recovery from past tree clearance or an unprecedented loss of open, grassy savanna (Gillson 2015; Gillson and Marchant 2014; Parr et al. 2014). As mentioned above, palaeoecological data can also help in understanding the role of past management of fire and herbivores, and the effects of disruption of traditional fire management (Humphrey et al. 2020).

\subsection{CHALLENGES IN APPLICATION OF PALAEOECOLOGY TO BIODIVERSITY CONSERVATION IN AFRICA}

Despite the great potential for synergy between palaeoecology and conservation, practical collaboration between the two fields remains rare. Here I will identify some challenges for palaeoecology and suggest some ways forward for increasing the application of our work.

\subsubsection{Calibration}

Palaeoecological data as it is presented in Quaternary journals is not easy for conservation managers to use (Davies et al. 2014). They need to be translated into metrics that are more closely aligned with ecological parameters and ecosystem services that are usually the target of management goals (Davies and Bunting 2010; Gillson and Marchant 2014). For example, a measure of changes in tree density is much more useful in conservation than a measure of arboreal pollen abundance (Gillson and Duffin 2007). Therefore, good calibration is needed 
between palaeo-proxies and ecological parameters, but calibration remains a major and barely addressed issue in palaeoecological studies of most African ecosystems (Julier et al. 2018). Accurate calibration that includes a measure of confidence limits will allow translation of pollen data to estimates of changing vegetation composition that are much more useful to managers. Much more work is needed in this regard, especially in Africa, where quantitative, multi-proxy data could be invaluable in understanding the feedbacks occur between climate, vegetation, fire and herbivory (Julier et al., 2021, this volume).

The same can be said of charcoal and spore data. Charcoal can be invaluable for reconstructing fire history, but it is also notoriously difficult to interpret, requiring comprehensive calibration efforts (Adolf et al. 2018). This is partly because different fire intensities affect the completeness of combustion and different fuel sources (e.g. grass versus woody vegetation) and thus their representation in the charcoal record (Leys et al. 2017). Amalgamation and metaanalyses of multiple charcoal data sets via the Global Charcoal data base can help in quantifying the relationship between biomass burning and charcoal representation (Hawthorne et al. 2018; Marlon et al. 2016). Emerging techniques such as Fourier Transform Infrared Spectroscopy can help in unravelling the complexity between fire intensity and charcoal representivity (Gosling et al. 2019). Similarly, studies suggest that Sporomiella alone do not seem to accurately represent herbivore density in African ecosystems (Baker et al. 2013). A suite of spore proxies is needed, and more quantitative work is required to relate these to herbivore biomass and if possible to different herbivore guilds (Feranec et al. 2011; Goethals and Verschuren 2019).

As well as the use of modern data sets, there is also potential for calibrating palaeoecological data against instrumental records of climate change (Jacques et al. 2015; Vallè et al. 2018), satellite imagery of fire, e.g. the MODIS data set (Adolf et al. 2018) and historical records of herbivory numbers fire (Baker et al. 2013, van Asperen et al. 2020).

\subsubsection{Chronologies and influx rates}

Calibration against instrumental records requires detailed and accurate chronologies, in order to compare measured changes in historical and palaeoecological records. Where such chronologies are available, pollen influx rates can be used. Influx rates have advantages over both percentage data, which are influenced by the Fagerlind effect (Fagerlind 1952), and concentration data, which are influenced by changes in sediment accumulation rate. In the case of pollen percentages, the change in the abundance of any particular plant will affect the abundance of all other taxa present, because the total pollen sum always has to be $100 \%$, regardless of how much biomass is present in the landscape. Similarly, a faster (slower) rate of sediment accumulation may lead to reductions (increases) in pollen concentration, even if the abundance of a plant in the landscape has not changed. However, such detailed chronologies are rarely found in palaeoecological data from semi-arid areas, where there are often hiatuses in sediment accumulation due to extended dry periods, and bioturbation by large mammals. In such cases, influx rates are not reliable, but careful comparison of percentage and concentration data can assist interpretation. There can be more confidence that trends observed in both percentage and concentration data reflect real changes in plant abundance (Baker et al. 2013; Forbes et al. 2018).

\subsubsection{Taxonomic resolution}

A further challenge in the application of fossil pollen data in biodiversity conservation is taxonomic resolution. Important ecological changes with implications for biodiversity conservation often occur at the species and genus level. For example, loss of species is a major concern for conservationists and changes in habitat quality, such as a shift from palatable to unpalatable grasses can have conservation management implications. Complementary proxies e.g. phytoliths can help to reserve poorly resolved but ecologically important families such as the Poaceae (Breman 
et al. 2019). Further, detailed work is needed on the pollen morphology and associated ecological affinity of taxa within diverse families, such as the Asteraceae, containing both generalist and specialist species (Blackmore et al. 2010). Environmental DNA from sediments (sedaDNA) is increasingly used to provide accurate taxonomic resolution (Bálint et al. 2018; Clarke et al. 2019), though further work is needed to improve coverage of African species in genomic databases (Dommain et al. 2020).

\subsubsection{Engagement with ecological theory}

Increasing the use of palaeoecology in conservation requires that palaeoecologists engage with relevant theoretical and management frameworks. The shift from 'balance of nature' to 'flux of nature' as the underlying paradigm in ecology, has had profound implications for conservation (Gillson 2015; Pickett et al. 1997). Specifically, managing ecosystems and populations that are not at equilibrium requires a different approach to old approaches to conservation that aimed to prevent change. Ecosystem management emerged in response to develop conservation approaches that accepted the heterogeneous, dynamic nature of ecosystems (Grumbine 1997). Working with variable ecosystems in which disturbance and change are normal, raises the need for information on variability over ecologically relevant timescales, in order to define conservation goals that are based on processes rather than states (Gillson 2015). Many ecosystems are dynamic and fluctuate in response to disturbance and environmental change, however longterm data are needed to help managers to identify when ecosystems are approaching 'tipping points' or novel states. There is a natural synergy between palaeoecology and resilience theory (Davies et al. 2018), in that hypotheses generated regarding resilience and thresholds in ecosystems can potentially be tested using palaeoecological data (Gillson et al. 2020; Seddon et al. 2011).

\subsubsection{Theory to application: relevance to current conservation questions}

Once palaeoecological data is calibrated into forms that are recognisable to ecologists and managers, there still remains the challenge of how to apply these data to current conservation questions. As well as climate-changed-integrated conservation strategies, mentioned above, an important interface between conservation practice and palaeoecological data is establishing acceptable limits of variation in key parameters such as woody vegetation cover, herbivore density and fire regimes. Recent trends in such parameters can be compared against data spanning decades and centuries, helping to quantifying the historical range of variability and the extent of intensifying human management, including the impact of changes in fire and fauna as well as land use implemented by colonial governments (Gell et al. 2012; Hoffman et al. 2019). Measures of the long-term variability can help to identify unprecedented change from normal background variability (Keane et al. 2009). Thus, long-term data from palaeoecology can help to understand the ecological character of an ecosystem. For example, palaeoecological data could potentially be incorporated into definitions of ecological characters, limits of acceptable change and Thresholds of Potential Concern (TPCs) (Gell 2010; Gillson and Duffin 2007).

Knowledge of long-term change is central to restoration ecology and rewilding. In restoration ecology, conservationists need to have a reference state (Falk 2017; Higgs et al. 2014; Nogué et al. 2017). While this is often a nearby undisturbed or little disturbed site, such locations are not always available. Indeed, even those that are perceived to be undisturbed may have a more complex history than can be gleaned from present day conditions (Forbes et al. 2018; Gell 2010). Thus, restoration targets including the rewilding of ecosystems requires data from before the intensive human impact of the 18th and 19th century. On the theme of restoration, there is a tendency to view grassy and other open ecosystems as less valuable than forests or woody systems, therefore their afforestation is prioritised (Bond et al. 2019; Parr et al. 2014). This tendency 
has become even more pronounced given recent drives to encourage tree planting as a means of enhancing carbon storage (Bastin et al. 2019). In some cases, where forest cover has become denuded or degraded, reforestation with native species can enhance biodiversity conservation and carbon storage at the same time (Lewis et al. 2019). In others, however, ancient grasslands and heathlands have been mistakenly identified as degraded or anthropogenically derived (Bond et al. 2019; Parr et al. 2014). This has led to inappropriate afforestation schemes that threaten rare open landscapes that are home to unique biodiversity (Bond et al. 2019; Veldman 2016; Veldman et al. 2019). Palaeoecology should therefore support the protection of open ecosystems and in the design of appropriate forest restoration programmes while at the same time raising the profile of ancient grasslands and heathlands as valid conservation targets.

A further step in the translation of palaeoecological data for conservation purposes is to convert them to indices for ecosystem services, such as biodiversity, sediment regulation, soil stability, sediment quality, and water quality (Dearing et al. 2012). This approach can help engage stakeholders by alerting them to changes in key services, information which could potentially inform sustainable management of natural resources, but to date has rarely been applied in Africa.

\subsubsection{Integrating with other disciplines and knowledge streams}

A multiproxy approach that helps to elucidate the complexities of landscape history and people's role in shaping the environment can help to build a nuanced and inclusive understanding of landscape history that can provide cultural and local context for interpreting change and informing future sustainable management (Gillson 2015; Githumbi et al. 2020; Marchant and Lane 2014; Mustaphi et al. 2019; Richer and Gearey 2018). Though much palaeoecological research occurs in the lab and behind the microscope, a key component of our work can be in collaborating with stakeholders and listening to stakeholder perspective on ecosystem change (Wolfe et al. 2007). Projects can be co-designed with stakeholders with their management needs and goals in mind (Rogers et al. 2013; Wolfe et al. 2007). Palaeoecologists can attend conservation conferences and workshops where managers and ecologists articulate questions that can be usefully addressed using palaeoecological techniques, or arranging consultations with community groups (Davies et al. 2014; Wolfe et al. 2007). Where palaeo-projects are already underway, it is useful to meet with communities, government, parastatals and NGOs while in the field, explain the potential utility of the palaeoecological data and to explore questions of mutual interest.

After a project's completion, it is useful to provide results in more than one format. Scientific publications are not always the most accessible or useful way in communicating results to stakeholders, formats such as reports, poster, or stakeholder feedback workshop might be more convienient. Such workshops are especially valuable when stakeholders can help in shaping elements of the project e.g. in adding insights to possible feedbacks between drivers and/or in utilising project outputs such as model-based tools that allow them to explore the effects of different scenarios or fire, herbivory and climate (Capitani et al. 2019; Hossain et al. 2020). Stakeholders often have different perspectives on how ecosystem change affects their livelihoods and there are often important cultural components of landscape change that can only be captured through consultation with stakeholders.

\subsubsection{The importance of modelling and future scenarios}

Reconstructing the past does not always provide analogues for the future (Williams and Jackson 2007). We face unprecedented rates of climate change and human impact, as well as social and economic structures that differ vastly from the past, as well as potentially novel combinations of climate parameters and anthropogenic stressors that may produce ecological surprises (Lindsey 
et al. 2020; Williams and Jackson 2007). Nevertheless, understanding past ecological dynamics can help to elucidate the interactions and processes that drive ecosystem change. Building models based on palaeoecological data that simulate past interactions between key drivers and responders e.g. vegetation, climate, fire and herbivory provides a basis for exploring future scenarios, especially where palaeoecological proxies have been turned into Ecosystem Service Indicators (see above) (Dearing et al. 2012; Perry et al. 2016).

Models based on palaeoecological data can simulate past interactions between human and environmental factors, for example, climate, fire, herbivory and vegetation (Perry et al. 2016). Such models can then be parameterised using current and future scenarios. Furthermore, some modelling approaches, such as system dynamics models offer opportunities for combining insights from long-term data with local knowledge of ecosystem change, complexity and likely future scenarios (Hossain et al. 2020). This has the twofold advantage of improving the relevance and applicability of palaeoecology whilst also improving access to a diverse range of voices in scenario planning and conservation management. Though highly uncertain, such models can help stakeholders to explore different possible future scenarios of land cover and ecosystem services (Caves et al. 2013).

\subsection{CONCLUSIONS}

Africa's landscapes are dynamic and complex, and managing them requires flexible and adaptive conservation approaches that safeguard biodiversity as well as providing ecosystem services and respecting indigenous knowledge. This means embracing a past-present-future perspective that includes a knowledge of ecosystem variability, ecological function as well as cultural heritage and the role of traditional management. There is thus enormous potential for better integration of palaeoecological and other long-term data into biodiversity conservation and natural resource management.

Carrying out palaeoecological research in Africa has some challenges, however, including the lack of sites and poor pollen preservation in semi-arid areas and the sheer diversity of the flora in forested areas. Despite this, the discipline has enormous potential value in conserving African biodiversity, especially as landscape history is often not well understood. Fine resolution studies covering the late Holocene are especially valuable to conservationists in understanding the impacts of climate change, the role of fire and herbivory, the effects of human management and the resilience of ecosystems. To realise this value, however, we in the palaeo-community must do our best to make our data accessible, and to present it in forms that are relevant to conservation. Aligning multiple proxies can help in distinguishing climatically driven from anthropogenically driven changes and provide the basis for defining restoration targets and thresholds of potential concern. Ensure that our research process is inclusive can contribute to building a nuanced and interdisciplinary understanding of landscape history that informs biodiversity conservation and the sustainable and equitable management of natural resources.

\section{ACKNOWLEDGEMENTS}

Many thanks to Timm Hoffman and two anonymous reviewers for helpful comments on the manuscript. The NRF Competitive Programme for Rated Researcher (Grant Number 118538), African Origins Platform (Grant number 117666), and Global Change Grand Challenge/SASSCAL (Grant number 118589) provided funding for some of the research underpinning this perspective. 


\section{REFERENCES}

Adolf, C., Doyon, F., Klimmek, F. and Tinner, W., 2018, Validating a continental European charcoal calibration dataset. The Holocene 28, pp. 1642-1652, 10.1177/0959683618782607.

Archer, E.R., Dziba, L., Mulongoy, K., Maoela, M.A. and Walters, M., 2018, The IPBES regional assessment report on biodiversity and ecosystem services for Africa. 3947851057, Intergovernmental Science-Policy Platform on Biodiversity and Ecosystem.

Baker, A.G., Bhagwat, S.A. and Willis, K.J., 2013, Do dung fungal spores make a good proxy for past distribution of large herbivores? Quaternary Science Reviews 62, pp. 21-31, 10.1016/ j.quascirev.2012.11.018.

Bálint, M., Pfenninger, M., Grossart, H.-P., Taberlet, P., Vellend, M., Leibold, M.A., Englund, G. and Bowler, D., 2018, Environmental DNA time series in ecology. Trends in Ecology \& Evolution 33, pp. 945-957, 10.1016/j.tree.2018.09.003.

Bastin, J.-F., Finegold, Y., Garcia, C., Mollicone, D., Rezende, M., Routh, D., Zohner, C.M. and Crowther, T.W., 2019, The global tree restoration potential. Science 365, pp. 76-79, $10.1126 /$ science.aax 0848 .

Beinart, W. 2003, The Rise of Conservation in South Africa: Settlers, Livestock, and the Environment 1770-1950. Oxford University Press, Oxford.

Blackmore, S., Wortley, A.H., Skvarla, J.J., Gabarayeva, N.I. and Rowley, J.R., 2010, Developmental origins of structural diversity in pollen walls of Compositae. Plant Systematics and Evolution 284, pp. 17-32, 10.1007/s00606-009-0232-2.

Blair, D., Shackleton, C.M. and Mograbi, P.J., 2018, Cropland abandonment in South African smallholder communal lands: Land cover change (1950-2010) and farmer perceptions of contributing factors. Land 7, pp. 121, 10.3390/land7040121.

Bond, W.J., and Midgley, G.F., 2012, Carbon dioxide and the uneasy interactions of trees and savannah grasses. Philosophical Transactions of the Royal Society B 367, pp. 601-612, 10.1098/rstb.2011.0182.

Bond, W.J., Stevens, N., Midgley, G.F. and Lehmann, C.E., 2019, The trouble with trees: afforestation plans for Africa. Trends in Ecology \& Evolution 34, pp. 963-965, 10.1016/ j.tree.2019.08.003.

Bond, W.J., Woodward, F.I. and Midgley, G.F., 2005, The global distribution of ecosystems in a world without fire. New Phytologist 165, pp. 525-538, 10.1111/j.1469-8137.2004.01252.x.

Bowman, D.M., O’Brien, J.A. and Goldammer, J.G., 2013, Pyrogeography and the global quest for sustainable fire management. Annual Review of Environment and Resources 38, p. 57, 10.1146/annurev-environ-082212-134049.

Breman, E., Ekblom, A., Gillson, L. and Norström, E., 2019, Phytolith-based environmental reconstruction from an altitudinal gradient in Mpumalanga, South Africa, 10,600 BP-present. Review of Paleobotany and Palynology 263, pp. 104-116, 10.1016/j.revpalbo.2019.01.001.

Burney, D.A., Robinson, G.S. and Burney, L.P., 2003, Sporormiella and the late Holocene extinctions in Madagascar. Proceedings of the National Academy of Sciences 100, pp. 10800 10805, 10.1073/pnas.1534700100.

Capitani, C., Garedew, W., Mitiku, A., Berecha, G., Hailu, B.T., Heiskanen, J., Hurskainen, P., Platts, P.J., Siljander, M. and Pinard, F., 2019, Views from two mountains: Exploring climate change impacts on traditional farming communities of Eastern Africa highlands through participatory scenarios. Sustainability Science 14, pp. 191-203, 10.1007/s11625-018-0622-x.

Caves, J.K., Bodner, G.S., Simms, K., Fisher, L.A. and Robertson, T., 2013, Integrating collaboration, adaptive management, and scenario-planning: experiences at Las Cienegas National Conservation Area. Ecology and Society 18, article: 43, 10.5751/ES-05749-180343.

Chen, W., Ciais, P., Zhu, D., Ducharne, A., Viovy, N., Qiu, C. and Huang, C., 2020, Feedbacks of soil properties on vegetation during the Green Sahara period. Quaternary Science Reviews 240, article: 106389, 10.1016/j.quascirev.2020.106389. 
Clarke, C.L., Edwards, M.E., Brown, A.G., Gielly, L., Lammers, Y., Heintzman, P.D., AncinMurguzur, F.J., Bråthen, K.A., Goslar, T. and Alsos, I.G., 2019, Holocene floristic diversity and richness in northeast Norway revealed by sedimentary ancient DNA (seda DNA) and pollen. Boreas 48, pp. 299-316, 10.1111/bor.12357.

Cromsigt, J.P., te Beest, M., Kerley, G.I., Landman, M., le Roux, E. and Smith, F.A., 2018, Trophic rewilding as a climate change mitigation strategy? Philosophical Transactions of the Royal Society B: Biological Sciences 373, article: 20170440, 10.1098/rstb.2017.0440.

Davies, A., and Bunting, M., 2010, Applications of palaeoecology in conservation. Open Ecology Journal 3, pp. 54-67, 10.2174/1874213001003020054.

Davies, A.L., Colombo, S. and Hanley, N., 2014, Improving the application of long-term ecology in conservation and land management. Journal of Applied Ecology 51, pp. 63-70, 10.1111/1365-2664.12163.

Davies, A.L., Streeter, R., Lawson, I.T., Roucoux, K.H. and Hiles, W., 2018, The application of resilience concepts in palaeoecology. The Holocene 28, pp. 1523-1534, $10.1177 / 0959683618777077$.

Dearing, J.A., Yang, X., Dong, X., Zhang, E., Chen, X., Langdon, P.G., Zhang, K., Zhang, W. and Dawson, T.P., 2012, Extending the timescale and range of ecosystem services through paleoenvironmental analyses, exemplified in the lower Yangtze basin. Proceedings of the National Academy of Sciences 109, pp. E1111-E1120, 10.1073/pnas.1118263109.

Dommain, R., Andama, M., McDonough, M.M., Prado, N.A., Goldhammer, T., Potts, R., Maldonado, J.E., Nkurunungi, J.B. and Campana, M.G., 2020, The challenges of reconstructing tropical biodiversity with sedimentary ancient DNA: A 2200-year-long metagenomic record from Bwindi impenetrable forest, Uganda. Frontiers in Ecology and Evolution 8, article: 218, $10.3389 /$ fevo.2020.00218.

Ekblom, A. and Gillson, L., 2010, Dung fungi as indicators of past herbivore abundance, Kruger and Limpopo National Park. Palaeogeography, Palaeoclimatology, Palaeoecology 296, pp. 14-27, 10.1016/j.palaeo.2010.06.009.

Engelbrecht, C.J., Engelbrecht, F.A. and Dyson, L.L., 2013, High-resolution model-projected changes in mid-tropospheric closed-lows and extreme rainfall events over southern Africa. International Journal of Climatology 33, pp. 173-187, 10.1002/joc.3420.

Fagerlind, F. 1952, The real significance of pollen diagrams. Botanisker Notiser 105, pp. 185-224.

Fairhead, J. and Leach, M., 1996, Rethinking the Forest-Savanna Mosaic: Colonial Science and its Relics in West Africa. Pages 105-121 in M. Leach and R. Mearns, editors. The Lie of the Land. (James Currey: Oxford).

Falk, D.A. 2017, Restoration ecology, resilience, and the axes of change. Annals of the Missouri Botanical Garden 102, pp. 201-216, 10.3417/2017006.

Feranec, R.S., Miller, N.G., Lothrop, J.C. and Graham, R.W., 2011, The Sporormiella proxy and end-Pleistocene megafaunal extinction: a perspective. Quaternary International 245, pp. 333-338, 10.1016/j.quaint.2011.06.004.

Foden, W.B., Young, B.E., Akçakaya, H.R., Garcia, R.A., Hoffmann, A.A., Stein, B.A., Thomas, C.D., Wheatley, C.J., Bickford, D. and Carr, J.A., 2019, Climate change vulnerability assessment of species. Wiley Interdisciplinary Reviews: Climate Change 10, e551, $10.1002 /$ wcc. 551 .

Forbes, C.J., Gillson, L. and Hoffman, M.T., 2018, Shifting baselines in a changing world: Identifying management targets in endangered heathlands of the Cape Floristic Region, South Africa. Anthropocene 22, pp. 81-93, 10.1016/j.ancene.2018.05.001.

Fuhlendorf, S.D., Engle, D.M., Kerby, J. and Hamilton, R., 2009, Pyric herbivory: rewilding landscapes through the recoupling of fire and grazing. Conservation Biology 23, pp. 588-598, 10.1111/j.1523-1739.2008.01139.x. 
Gell, P. 2010, With the benefit of hindsight: the utility of palaeoecology in wetland condition assessment and identification of restoration targets. Ecology of Industrial Pollution. Ecological Review Series, (CUP \& the British Ecological Society: Cambridge), pp. 162-188.

Gell, P., Mills, K. and Grundell, R., 2012, A legacy of climate and catchment change: the real challenge for wetland management. Hydrobiologia 708, pp.1-12.

Gillson, L. 2015, Biodiversity Conservation and Environmental Change: Using palaeoecology to manage dynamic landscapes in the Anthropocene. Oxford University Press, Oxford, U.K.

Gillson, L. and Duffin, K.I., 2007, Thresholds of Potential Concern as benchmarks in the management of African savannahs. Philosophical Transactions of the Royal Society of London Series B-Biological Sciences 362, pp. 309-319, 10.1098/rstb.2006.1988.

Gillson, L., MacPherson, A.J. and Hoffman, M.T. 2020, Contrasting mechanisms of resilience at mesic and semi-arid boundaries of fynbos, a mega-diverse heathland of South Africa. Ecological Complexity 42, pp. 100827, 10.1016/j.ecocom.2020.100827.

Gillson, L. and Marchant, R., 2014, From myopia to clarity: sharpening the focus of ecosystem management through the lens of palaeoecology. Trends in Ecology \& Evolution 29, pp. 317-325, 10.1016/j.tree.2014.03.010.

Gillson, L., Whitlock, C. and Humphrey, G., 2019, Resilience and fire management in the Anthropocene. Ecology and Society 24(3), p.14, 10.5751/ES-11022-240314.

Githumbi, E., Marchant, R. and Olago, D., 2020, Using the Past to Inform a Sustainable Future: Palaeoecological Insights from East Africa. pp. 187-195 Africa and the Sustainable Development Goals. Springer.

Goethals, L. and Verschuren, D., 2020, Tracing ancient animal husbandry in tropical Africa using the fossil spore assemblages of coprophilous fungi: a validation study in western Uganda. Vegetation History and Archaeobotany 29, pp. 509-526, 10.1007/s00334-019-00760-3.

Gosling, W.D., Cornelissen, H. and McMichael, C. 2019, Reconstructing past fire temperatures from ancient charcoal material. Palaeogeography, Palaeoclimatology, Palaeoecology 520, pp. 128-137, 10.1016/j.palaeo.2019.01.029.

Grumbine, R.E. 1997, Reflections on Ecosystem Management. Conservation Biology 11, pp. 41-47, 10.1046/j.1523-1739.1997.95479.x.

Hannah, L., Midgley, G.F. and Millar, D., 2002, Climate change-integrated conservation strategies. Global Ecology \& Biogeography 11, pp. 485-495, 10.1046/j.1466-822X.2002.00306.x.

Hawthorne, D., Mustaphi, C.J.C., Aleman, J.C., Blarquez, O., Colombaroli, D., Daniau, A.-L., Marlon, J.R., Power, M., Vanniere, B. and Han, Y., 2018, Global Modern Charcoal Dataset (GMCD): A tool for exploring proxy-fire linkages and spatial patterns of biomass burning. Quaternary International 488, pp. 3-17, 10.1016/j.quaint.2017.03.046.

Hempson, G.P., Archibald, S. and Bond, W.J., 2015, A continent-wide assessment of the form and intensity of large mammal herbivory in Africa. Science 350, pp. 1056-1061, 10.1126/science.aac7978.

Higgs, E., Falk, D.A., Guerrini, A., Hall, M., Harris, J., Hobbs, R.J., Jackson, S.T., Rhemtulla, J.M. and Throop, W., 2014, The changing role of history in restoration ecology. Frontiers in Ecology and the Environment 12, pp. 499-506, 10.1890/110267.

Hoffman, M.T., Rohde, R.F. and Gillson, L., 2019, Rethinking catastrophe? Historical trajectories and modelled future vegetation change in southern Africa. Anthropocene 25, pp. 100189, 10.1016/j.ancene.2018.12.003.

Home, D.D. 1874, Incidents in my life. (AK Butts: New York).

Hoogendoorn, G., Meintjes, D., Kelso, C. and Fitchett, J., 2019, Tourism as an incentive for rewilding: the conversion from cattle to game farms in Limpopo province, South Africa. Journal of Ecotourism 18, pp. 309-315, 10.1080/14724049.2018.1502297.

Hossain, M.S., Ramirez, J., Szabo, S., Eigenbrod, F., Johnson, F.A., Speranza, C.I. and Dearing, J.A., 2020, Participatory modelling for conceptualizing social-ecological system dynamics in 
the Bangladesh delta. Regional Environmental Change 20, pp. 1-14, 10.1007/s10113-02001599-5.

Humphrey, G.J., Gillson, L. and Ziervogel, G., 2020, How changing fire management policies affect fire seasonality and livelihoods. Ambio, pp. 1-17, 10.1007/s13280-020-01351-7.

Jacques, J.-M.S., Cumming, B.F., Sauchyn, D.J. and Smol, J.P., 2015, The bias and signal attenuation present in conventional pollen-based climate reconstructions as assessed by early climate data from Minnesota, USA. PLoS ONE 10, e0113806, 10.1371/journal.pone.0113806.

Julier, A.C., Jardine, P.E., Adu-Bredu, S., Coe, A.L., Duah-Gyamfi, A., Fraser, W.T., Lomax, B.H., Malhi, Y., Moore, S., Owusu-Afriyie, K. and Gosling, W.D., 2018, The modern pollenvegetation relationships of a tropical forest-savannah mosaic landscape, Ghana, West Africa. Palynology 42, pp. 324-338, 10.1080/01916122.2017.1356392.

Julier, A.C.M., Manzano, S., Razanatsoa, E., Razafimanantsoa, A.H.I., Githumbi, E., Hawthorne, D., Oden, G., Schüler, L., Tossou, M., Bunting, M.J., this volume, Modern pollen studies from tropical Africa and their use in palaeoecology. Palaeoecology of Africa 35, 10.1201/9781003162766-21.

Keane, R.E., Hessburg, P.F., Landres, P.B. and Swanson, F.J., 2009, The use of historical range and variability (HRV) in landscape management. Forest Ecology and Management 258, pp. 1025-1037, 10.1016/j.foreco.2009.05.035.

Laris, P. 2011, Humanizing savanna biogeography: linking human practices with ecological patterns in a frequently burned savanna of southern Mali. Annals of the Association of American Geographers 101, pp. 1067-1088, 10.1080/00045608.2011.560063.

Lewis, S.L., Wheeler, C.E., Mitchard, E.T. and Koch, A. 2019, Regenerate natural forests to store carbon. Nature 568, pp. 25-28, 10.1038/d41586-019-01026-8.

Leys, B.A., Commerford, J.L. and McLauchlan, K.K., 2017, Reconstructing grassland fire history using sedimentary charcoal: Considering count, size and shape. PLOS ONE 12, e0176445, 10.1371/journal.pone.0176445.

Lézine, A.-M., Hély, C., Grenier, C., Braconnot, P. and Krinner, G., 2011, Sahara and Sahel vulnerability to climate changes, lessons from Holocene hydrological data. Quaternary Science Reviews 30, pp. 3001-3012, 10.1016/j.quascirev.2011.07.006.

Lindsey, P., Allan, J., Brehony, P., Dickman, A., Robson, A., Begg, C., Bhammar, H., Blanken, L., Breuer, T. and Fitzgerald, K., 2020, Conserving Africa's wildlife and wildlands through the COVID-19 crisis and beyond. Nature Ecology \& Evolution, pp. 1-11.

Lüning, S., Gałka, M., Danladi, I.B., Adagunodo, T.A. and Vahrenholt, F., 2018, Hydroclimate in Africa during the medieval climate anomaly. Palaeogeography, Palaeoclimatology, Palaeoecology 495, pp. 309-322, 10.1016/j.palaeo.2018.01.025.

Lüning, S., Gałka, M. and Vahrenholt, F., 2017, Warming and cooling: the medieval climate anomaly in Africa and Arabia. Paleoceanography 32, pp. 1219-1235, 10.1002/2017PA003237.

Marchant, R. and Lane, P., 2014, Past perspectives for the future: foundations for sustainable development in East Africa. Journal of Archaeological Science 51, pp. 12-21, 10.1016/j.jas.2013.07.005.

Marchant, R., Richer, S., Boles, O., Capitani, C., Courtney-Mustaphi, C.J., Lane, P., Prendergast, M.E., Stump, D., De Cort, G. and Kaplan, J.O., 2018, Drivers and trajectories of land cover change in East Africa: Human and environmental interactions from 6000 years ago to present. Earth-Science Reviews 178, pp. 322-378, 10.1016/j.earscirev.2017.12.010.

Marlon, J.R., Kelly, R., Daniau, A.-L., Vannière, B., Power, M.J., Bartlein, P., Higuera, P., Blarquez, O., Brewer, S. and Brücher, T., 2016, Reconstructions of biomass burning from sediment charcoal records to improve data-model comparisons. Biogeosciences (BG) 13, pp. 3225-3244, 10.5194/bg-13-3225-2016.

Midgley, G.F. and Bond, W.J., 2015, Future of African terrestrial biodiversity and ecosystems under anthropogenic climate change. Nature Climate Change 5, pp. 823-829, 10.1038/nclimate2753. 
Moura, L.C., Scariot, A.O., Schmidt, I.B., Beatty, R. and Russell-Smith, J., 2019, The legacy of colonial fire management policies on traditional livelihoods and ecological sustainability in savannas: impacts, consequences, new directions. Journal of Environmental Management 232, pp. 600-606, 10.1016/j.jenvman.2018.11.057.

Mustaphi, C.J.C., Capitani, C., Boles, O., Kariuki, R., Newman, R., Munishi, L., Marchant, R. and Lane, P., 2019, Integrating evidence of land use and land cover change for land management policy formulation along the Kenya-Tanzania borderlands. Anthropocene 28, pp. 100228, 10.1016/j.ancene.2019.100228.

Nogué, S., de Nascimento, L., Froyd, C.A., Wilmshurst, J.M., de Boer, E.J., Coffey, E.E., Whittaker, R.J., Fernández-Palacios, J.M. and Willis, K.J., 2017, Island biodiversity conservation needs palaeoecology. Nature Ecology \& Evolution 1, pp. 0181, 10.1038/s41559-017-0181.

O'Connor, T.G., Puttick, J.R. and Hoffman, M.T., 2014, Bush encroachment in southern Africa: changes and causes. African Journal of Range \& Forage Science 31, pp. 67-88, 10.2989/10220119.2014.939996.

Parr, C. and Brockett, B.H., 1999, Patch-mosaic burning: a new paradigm for savanna fire management in protected areas. Koedoe 42, pp. 117-130, 10.4102/koedoe.v42i2.237.

Parr, C.L., Lehmann, C.E., Bond, W.J., Hoffmann, W.A. and Andersen, A.N., 2014, Tropical grassy biomes: misunderstood, neglected, and under threat. Trends in Ecology \& Evolution 29, pp. 205-213, 10.1016/j.tree.2014.02.004.

Pausata, F.S., Gaetani, M., Messori, G., Berg, A., de Souza, D.M., Sage, R.F. and deMenocal, P.B., 2020, The Greening of the Sahara: Past Changes and Future Implications. One Earth 2, pp. 235-250, 10.1016/j.oneear.2020.03.002.

Perry, G.L., Wainwright, J., Etherington, T.R. and Wilmshurst, J.M., 2016, Experimental simulation: using generative modeling and palaeoecological data to understand human-environment interactions. Frontiers in Ecology and Evolution 4, pp. 109, 10.3389/fevo.2016.00109.

Pickett, S.T.A., Ostfeld, R.S., Shachak, M. and Likens, G.E., editors. 1997, The Ecological Basis of Conservation; Heterogeneity, Ecosystems, and Biodiversity. Chapman and Hall, New York.

Pinto, I., Jack, C. and Hewitson, B., 2018, Process-based model evaluation and projections over southern Africa from coordinated regional climate downscaling experiment and coupled model intercomparison project phase 5 models. International Journal of Climatology 38, pp. 4251-4261, 10.1002/joc.5666.

Pohl, B., Macron, C. and Monerie, P.-A., 2017, Fewer rainy days and more extreme rainfall by the end of the century in Southern Africa. Scientific Reports 7, pp. 1-7, 10.1038/srep46466.

Rachmayani, R., Prange, M. and Schulz, M., 2015, North African vegetation-precipitation feedback in early and mid-Holocene climate simulations with CCSM3-DGVM. Climate of the Past 11, 10.5194/cp-11-175-2015.

Richer, S. and Gearey, B., 2018, From Rackham to REVEALS: reflections on palaeoecological approaches to woodland and trees. Environmental Archaeology 23, pp. 286-297, 10.1080/14614103.2017.1283765.

Rogers, K.H., Luton, R., Biggs, H., Biggs, R.O., Blignaut, S., Choles, A.G., Palmer, C.G. and Tangwe, P., 2013, Fostering Complexity Thinking in Action Research for Change in SocialEcological Systems. Ecology \& Society 18, p. 31 http://dx.doi.org/10.5751/ES-05330-180231.

Seddon, A., Froyd, C., Leng, M., Milne, G. and Willis, K., 2011, Ecosystem Resilience and Threshold Response in the Galápagos Coastal Zone. PLoS ONE 6, e22376, 10.1371/journal. pone. 0022376 .

Skead, C.J., Boshoff, A., Kerley, G.I.H. and Lloyd, P., 2007, Historical incidence of the larger land mammals in the broader Eastern Cape. Centre for African Conservation Ecology, Nelson Mandela Metropolitan.

Tierney, J.E., Pausata, F.S. and deMenocal, P.B., 2017, Rainfall regimes of the Green Sahara. Science advances 3, e1601503, 10.1126/sciadv.1601503. 
Vallè, F., Brunetti, M., Pini, R., Maggi, V. and Ravazzi, C., 2018, Testing pollen-climate models over the last 200 years in N-Italy using instrumental data. Alpine and Mediterranean Quaternary 31, pp. 165-168.

van Asperen, E.N., Kirby, J.R. and Shaw, H.E., 2020, Relating dung fungal spore influx rates to animal density in a temperate environment: Implications for palaeoecological studies. The Holocene 30, pp. 218-232, 10.1177/0959683619875804.

van Wilgen, B.W., Govender, N., Smit, I.P. and MacFadyen, S., 2014, The ongoing development of a pragmatic and adaptive fire management policy in a large African savanna protected area. Journal of Environmental Management 132, pp. 358-368, 10.1016/j.jenvman.2013.11.003.

Veldman, J.W. 2016, Clarifying the confusion: old-growth savannahs and tropical ecosystem degradation. Philosophical Transactions of the Royal Society B: Biological Sciences 371, pp. 20150306, 10.1098/rstb.2015.0306.

Veldman, J.W., Aleman, J.C., Alvarado, S.T., Anderson, T.M., Archibald, S., Bond, W.J., Boutton, T.W., Buchmann, N., Buisson, E. and Canadell, J.G., 2019, Comment on "The global tree restoration potential". Science 366, 10.1126/science.aay7976, eaay7976.

Venter, Z.S., Hawkins, H.J. and Cramer, M.D., 2017, Implications of historical interactions between herbivory and fire for rangeland management in African savannas. Ecosphere 8, pp. e01946, 10.1002/ecs2.1946.

Wigley, B.J., Bond, W.J. and Hoffman, M.T., 2009, Bush encroachment under three contrasting land-use practices in a mesic South African savanna. African Journal of Ecology 47, pp. 62-70, 10.1111/j.1365-2028.2008.01051.x.

Williams, J.W. and Jackson, S.T., 2007, Novel climates, no-analog communities, and ecological surprises. Frontiers in Ecology and the Environment 5:475-482, 10.1890/070037.

Willis, K.J., Gillson, L. and Brncic, T., 2004, How "Virgin" is Virgin Rainforest. Science 304, pp.402-403, 10.1126/science.1093991.

Wolfe, B.B., Armitage, D., Wesche, S., Brock, B.E., Sokal, M.A., Clogg-Wright, K.P., Mongeon, C.L., Adam, M.E., Hall, R.I. and Edwards, T.W., 2007, From isotopes to TK interviews: towards interdisciplinary research in Fort Resolution and the Slave River Delta, Northwest Territories. Arctic, pp.75-87. 